\title{
Effect of Radiofrequency Waves of Mobile Phones on Distortion Product Otoacoustic Emissions
}

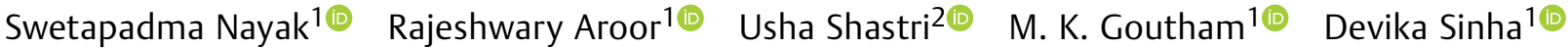 \\ 1 Department of Otorhinolaryngology, Nitte (Deemed to be University), KS \\ Hegde Medical Academy, Mangalore, Karnataka, India \\ 2 Department of Audiology and Speech Language Pathology, Manipal \\ Academy of Higher Education, Kasturba Medical College, Karnataka,

\begin{abstract}
Address for correspondence Rajeshwary Aroor, MBBS, MS(ENT), Department of Otorhinolaryngology, Nitte (Deemed to be University), KS Hegde Medical Academy, Mangalore 575018,
\end{abstract} \\ Karnataka, India (e-mail: rajeshwarisomayaji@gmail.com).
} India

J Health Allied Sci ${ }^{\mathrm{NU}} 2022 ; 12: 119-125$.

\begin{abstract}
Keywords

- mobile phone

- otoacoustic emission

- hearing loss

Objective The prolonged exposure to electromagnetic fields of mobile phones can damage the cochlear hair cells, which can be detected by otoacoustic emission (OAE). To know the effect of mobile phones on hearing, the young volunteers were subjected to prolonged mobile phone usage and changes in OAE were recorded.

Materials and Methods Twenty-eight volunteers with normal hearing were made to talk one full hour continuously on the mobile phone. Distortion product otoacoustic emission (DPOAE) was measured prior to the usage of mobile phones and immediately after the use (post-exposure 1 ) and 24 hours after the use (post-exposure 2 ). The values were compared.

Results Out of the 28 volunteers, 20 were females and 8 were males. Twenty-one volunteers preferred the right ear while using mobile phones, 7 preferred the left ear. There was no statistically significant difference between the baseline DPOAE values and values of post-exposure 1 and 2 when only the preferred ear was taken into consideration. When the preferred ear was compared with nonpreferred ear, a statistically significant difference was found only in the low frequencies between the pre-exposure and post-exposure 1 values.

Conclusion This study shows there was no significant correlation between OAE and prolonged mobile phone exposure when the preferred ear was not considered.
\end{abstract}

\section{Introduction}

In the past few decades, wireless communication has become a part of our life. We have seen the revolution in the field of mobile communication from $1 \mathrm{G}$ (first generation) in the year 1981 to 3G (third generation) and 4G (fourth generation) in recent years. ${ }^{1}$

The mobile phones that are currently in use are based on GSM (global system for mobile communications), WCDMA (wideband code-division multiple access), Wi-Max (worldwide interoperability for microwave access), and LTE (longterm evolution) and work at $900 \mathrm{MHz}$ (Megahertz), $2100 \mathrm{MHz}, 2300 \mathrm{MHz}, 1800 \mathrm{MHz}$, respectively. ${ }^{1,2}$ The exposure to radiofrequency electromagnetic fields (RF-EMFs) on health is a worrying factor in recent times. Even when mobile phones are not in use, they are always in an active state with constant connection from the service provider. Many other powerful sources emit an intense electromagnetic field, but
DOI https://doi.org/ $10.1055 / \mathrm{s}-0041-1736272$. ISSN 2582-4287. (c) 2021. Nitte (Deemed to be University). All rights reserved. This is an open access article published by Thieme under the terms of the Creative Commons Attribution-NonDerivative-NonCommercial-License, permitting copying and reproduction so long as the original work is given appropriate credit. Contents may not be used for commercial purposes, or adapted, remixed, transformed or built upon. (https://creativecommons.org/ licenses/by-nc-nd/4.0/)

Thieme Medical and Scientific Publishers Pvt. Ltd., A-12, 2nd Floor, Sector 2, Noida-201301 UP, India 
they have a lower effect on human beings as they are far from human dwellings.

Because mobile phone handsets are held next to the ear, these impact the surrounding tissues as they emit radio frequencies when being used and communicate with the service provider. Even though these emit a lower level of energy, they still cause warming of the ear. The energy waves penetrate the skull and transfer energy into the brain, leading to a potential rise in the temperature of $\sim 0.11^{\circ} \mathrm{C}$. This is more often seen in the newer handsets such as smartphones (digital) than the old, analog models. ${ }^{3,4}$

Otoacoustic emissions (OAE) are the sounds generated by the cochlear outer hair cells, recorded by a microphone kept in the external auditory canal. OAEs are simple and efficient indicators of healthy cochlear functions. It is well known that outer hair cells are most vulnerable to various forms of ototoxicity. Cochlear outer hair cell damage caused by prolonged exposure to electromagnetic fields generated by mobile phones can be detected by an OAE test. We performed this study to know the effects of mobile phones on cochlear outer hair cell function using distortion product (DP) OAE in volunteers subjected to prolonged mobile phone usage for $1 \mathrm{~h}$.

\section{Materials and Methods}

This is a prospective cross-sectional study, where 28 medical student volunteers aged between $20 \pm$ two years with normal hearing and normal ear findings on examination who used mobile phones for more than 3 to $4 \mathrm{~h}$ per day over 5 to 7 years. Institutional ethical committee approval was taken for the study. After the written informed consent was obtained, the volunteers were subjected to a pure tone audiogram to know the hearing level. Volunteers with pure tone average better than $25 \mathrm{~dB}(\mathrm{~dB})$ for frequencies 500,1000 , and $2000 \mathrm{~Hz}$ were considered as having normal hearing. All volunteers with normal hearing were subjected to prolonged mobile phone use using smartphones (GSM) for $1 \mathrm{~h}$, continuously keeping the phone within a $2 \mathrm{~cm}$ distance from the ear. They were made to talk in a quiet room with a background noise level of roughly around $50 \mathrm{~dB}$. The preferred ear of the subject was noted. The consistent choice of one ear or preponderance to hear from one ear was considered as the preferred ear (dominant ear). Using GSI Audera by VIASYS healthcare instrument, the OAE test was performed prior to the mobile phone use (baseline), and the test was repeated immediately after the use. Repeat OAE was done again after $24 \mathrm{~h}$, during which the volunteers were restrained from using mobile phones.

Volunteers with pre-existing ear pathology, acute otitis media, chronic otitis media, those suffering from upper respiratory tract infection, history of chronic exposure to loud sounds, history of consumption of ototoxic medication, and hearing loss were excluded from the study.

After sealing the external auditory canal and placing a low noise microphone in the canal, the OAE was recorded. The auditory function was assessed using DP (represented as 2f1f2 for two different frequencies). Clinically, the levels of the primary two tones were set at $65 \mathrm{~dB}$ sound pressure level (SPL) and $55 \mathrm{~dB}$ SPL. A $6 \mathrm{~dB}$ amplitude to noise ratio was considered as a response. For interpretation of results, the amplitude of the DPOAE was compared with the normal values. The differences in DPOAE at baseline, immediately after exposure (post exposure 1), and after $24 \mathrm{~h}$ (post exposure 2) were compared. To compare the values, analysis of variance (ANOVA) was used. If data did not follow the normal distribution, Friedman's ANOVA, Student's $t$-test, and MannWhitney $U$ test were used (inferential statistics). The $p$-value less than 0.05 was considered significant. ${ }^{5}$

\section{Results}

A total of 28 volunteers who fulfilled the inclusion criteria were included in the study. Out of them, 20 subjects (71\%) were females and 8 subjects (29\%) were males. Twenty-one volunteers had right ear dominance (preferred ear) (75\%) and seven volunteers (25\%) had left ear dominance.

There were no significant differences between the DPOAE values at baseline, post-exposure one, and post-exposure 2 when the preferred ear was not considered ( - Table $\mathbf{1}$ ). There were no statistically significant differences between the DPOAE values in baseline evaluation when the preferred ear was compared with the nonpreferred ear, except for frequency $1371 \mathrm{~Hz}$ on the left preferred ear ( - Table 2). Mean DPOAE values for frequencies 1031,1371, and 2098 in the left preferred ear were statistically significant in post-exposure 1 , whereas the mean values for higher frequencies were not statistically significant when the preferred ear was compared with the nonpreferred ear (-Table 3 ). The mean DPOAE values of post-exposure 2 were not statistically significant when the preferred ear was compared with the nonpreferred ear (-Table 4 ). When only the preferred ear was considered, there was no significant difference between the baseline value and post-exposure 1 values. Similarly, when baseline values were compared with values of postexposure 2, no significant difference was found (-Table 5).

\section{Discussion}

Mobile phones are an easy and accessible mode of communication and have a significant impact on our social lives. We have reached a point in society where we are highly dependent on these gadgets. Mobile phones have become no longer a luxury, but they have become a daily necessity. Hence it is important to study whether this tiny gadget has any serious implications on our health.

Some of the recent studies have tried to link the exposure of electromagnetic radiations to increased risk of cancers (e.g., leukemia, brain tumors, lymphomas), various neurological diseases, sleep disturbances, genotoxic effects, increased risk of hypothyroidism, brain development of children, general microwave syndrome, increase in blood pressure, etc. $^{6-12}$

The ear, being in close relation with the mobile phone, is at high risk because of electromagnetic radio waves. ${ }^{13}$ There is a hypothesis that the usage of mobile phones is known to cause acoustic neuroma. ${ }^{14,15}$ Long-term exposure to electromagnetic fields produced by mobile phones has been shown 
Table 1 Comparison of DPOAE values at baseline, immediately after exposure, and 24 hours after exposure without preference ear was considered

\begin{tabular}{|c|c|c|c|c|c|}
\hline $\begin{array}{l}\text { Frequency } \\
(\mathrm{Hz})\end{array}$ & $\begin{array}{l}\text { Side of } \\
\text { the ear }\end{array}$ & Test & $\begin{array}{l}\text { Mean } \\
\text { SPL }\end{array}$ & Standard deviation & $\begin{array}{l}\text { Friedman's } \\
\text { Test } p \text {-value }\end{array}$ \\
\hline \multirow[t]{6}{*}{6340} & \multirow[t]{3}{*}{ Left } & Baseline & 9.94 & 6.9 & \multirow[t]{3}{*}{0.916} \\
\hline & & Postexp. 1 & 10.18 & 6.89 & \\
\hline & & Postexp. 2 & 10.17 & 8.78 & \\
\hline & \multirow[t]{3}{*}{ Right } & Baseline & 11.31 & 7.45 & \multirow[t]{3}{*}{0.204} \\
\hline & & Postexp. 1 & 9.16 & 6.51 & \\
\hline & & Postexp. 2 & 10.40 & 8.81 & \\
\hline \multirow[t]{6}{*}{4814} & \multirow[t]{3}{*}{ Left } & Baseline & 18.29 & 7.10 & \multirow[t]{3}{*}{0.302} \\
\hline & & Postexp. 1 & 17.75 & 7.11 & \\
\hline & & Postexp. 2 & 20.71 & 7.24 & \\
\hline & \multirow[t]{3}{*}{ Right } & Baseline & 20.47 & 7.53 & \multirow[t]{3}{*}{0.164} \\
\hline & & Postexp. 1 & 19.10 & 6.74 & \\
\hline & & Postexp. 2 & 22.61 & 7.46 & \\
\hline \multirow[t]{6}{*}{3152} & \multirow[t]{3}{*}{ Left } & Baseline & 15.32 & 5.9 & \multirow[t]{3}{*}{0.509} \\
\hline & & Postexp. 1 & 13.69 & 5.61 & \\
\hline & & Postexp. 2 & 14.73 & 5.06 & \\
\hline & \multirow[t]{3}{*}{ Right } & Baseline & 16.5 & 6.09 & \multirow[t]{3}{*}{0.164} \\
\hline & & Postexp. 1 & 14.41 & 3.92 & \\
\hline & & Postexp. 2 & 15.81 & 5.34 & \\
\hline \multirow[t]{6}{*}{2098} & \multirow[t]{3}{*}{ Left } & Baseline & 12.74 & 6.71 & \multirow[t]{3}{*}{0.782} \\
\hline & & Postexp. 1 & 11.96 & 6.01 & \\
\hline & & Postexp. 2 & 12.67 & 4.82 & \\
\hline & \multirow[t]{3}{*}{ Right } & Baseline & 13.10 & 5.61 & \multirow[t]{3}{*}{0.084} \\
\hline & & Postexp. 1 & 12.23 & 5.07 & \\
\hline & & Postexp. 2 & 13.25 & 3.42 & \\
\hline \multirow[t]{6}{*}{1371} & \multirow[t]{3}{*}{ Left } & Baseline & 10.09 & 5.44 & \multirow[t]{3}{*}{0.302} \\
\hline & & Postexp. 1 & 9.59 & 5.48 & \\
\hline & & Postexp. 2 & 47.72 & 191.42 & \\
\hline & \multirow[t]{3}{*}{ Right } & Baseline & 11.73 & 4.52 & \multirow[t]{3}{*}{0.102} \\
\hline & & Postexp. 1 & 9.59 & 5.65 & \\
\hline & & Postexp. 2 & 12.14 & 4.84 & \\
\hline \multirow[t]{6}{*}{1031} & \multirow[t]{3}{*}{ Left } & Baseline & 8.09 & 4.39 & \multirow[t]{3}{*}{0.199} \\
\hline & & Postexp. 1 & 7.37 & 4.96 & \\
\hline & & Postexp. 2 & 8.93 & 4.6 & \\
\hline & Right & Baseline & 8.23 & 3.64 & 0.568 \\
\hline & & Postexp. 1 & 8.52 & 4.08 & \\
\hline & & Postexp. 2 & 8.82 & 3.79 & \\
\hline
\end{tabular}

Abbreviation: Postexp., post exposure.

to cause hearing loss at the cochlear level. ${ }^{16}$ Both longer daily usage of mobile phones and longer duration (years) of using mobile phones can lead to hearing loss. These may not be evident early as most audiometers used routinely are only up to $8 \mathrm{kHz}$. A high-frequency audiogram up to $16 \mathrm{kHz}$ is required to detect these early changes. ${ }^{16}$ Studies have shown that short-term exposure to electromagnetic waves of mobile phones for $10 \mathrm{~min}$ did not cause any change in both DPOAE $^{17}$ and transiently evoked OAE. ${ }^{18}$ Even 20 min of exposure did not cause any effect on the DPOAE. ${ }^{19}$

In the conventional sense, one would see individuals with their right hand occupied in work and the free left hand for 
122 Effect of Radiofrequency Waves of Mobile Phones Nayak et al.

Table 2 Comparison of DPOAE values at baseline with preference ear consideration

\begin{tabular}{|c|c|c|c|c|}
\hline Frequency $(\mathrm{Hz})$ & Preference & $\begin{array}{l}\text { Mean } \\
\text { SPL }\end{array}$ & $\begin{array}{l}\text { Standard } \\
\text { deviation }\end{array}$ & $\begin{array}{l}\text { Mann-Whitney } \\
U \text { test }\end{array}$ \\
\hline \multirow[t]{2}{*}{$6340(R)$} & Right & 11.65 & 7.42 & \multirow[t]{2}{*}{0.959} \\
\hline & Left & 10.27 & 8.06 & \\
\hline \multirow[t]{2}{*}{6340 (L) } & Right & 10.48 & 7.25 & \multirow[t]{2}{*}{0.435} \\
\hline & Left & 8.32 & 5.8 & \\
\hline \multirow[t]{2}{*}{$4814(\mathrm{R})$} & Right & 20.67 & 8.4 & \multirow[t]{2}{*}{0.533} \\
\hline & Left & 19.89 & 4.41 & \\
\hline \multirow[t]{2}{*}{$4814(\mathrm{~L})$} & Right & 18.38 & 7.62 & \multirow[t]{2}{*}{0.917} \\
\hline & Left & 18.03 & 5.76 & \\
\hline \multirow[t]{2}{*}{$3152(R)$} & Right & 17.2 & 6.23 & \multirow[t]{2}{*}{0.296} \\
\hline & Left & 14.4 & 5.55 & \\
\hline \multirow[t]{2}{*}{$3152(\mathrm{~L})$} & Right & 15.67 & 6.3 & \multirow[t]{2}{*}{0.678} \\
\hline & Left & 14.25 & 4.72 & \\
\hline \multirow[t]{2}{*}{$2098(R)$} & Right & 12.31 & 5.9 & \multirow[t]{2}{*}{0.189} \\
\hline & Left & 15.45 & 3.88 & \\
\hline \multirow[t]{2}{*}{$2098(L)$} & Right & 11.66 & 6.59 & \multirow[t]{2}{*}{0.348} \\
\hline & Left & 15.97 & 6.45 & \\
\hline \multirow[t]{2}{*}{$1371(R)$} & Right & 11.29 & 4.42 & \multirow[t]{2}{*}{0.348} \\
\hline & Left & 13.06 & 4.89 & \\
\hline \multirow[t]{2}{*}{$1371(\mathrm{~L})$} & Right & 8.89 & 5.53 & \multirow[t]{2}{*}{$0.055^{a}$} \\
\hline & Left & 13.67 & 3.33 & \\
\hline \multirow[t]{2}{*}{$1031(R)$} & Right & 7.81 & 3.95 & \multirow[t]{2}{*}{0.604} \\
\hline & Left & 9.49 & 2.29 & \\
\hline \multirow[t]{2}{*}{$1031(\mathrm{~L})$} & Right & 7.44 & 4.84 & \multirow[t]{2}{*}{0.604} \\
\hline & Left & 10.03 & 1.71 & \\
\hline
\end{tabular}

${ }^{a} p$-value is significant.

Table 3 Comparison of DPOAE values immediately after exposure with preference ear consideration

\begin{tabular}{|l|l|l|l|l|}
\hline Frequency (Hz) post exposure 1 & Preference & $\begin{array}{l}\text { Mean } \\
\text { SPL }\end{array}$ & $\begin{array}{l}\text { Standard } \\
\text { deviation }\end{array}$ & $\begin{array}{l}\text { Mann-Whitney } \\
\text { test }\end{array}$ \\
\hline \multirow{2}{*}{$6340(\mathrm{R})$} & Right & 8.85 & 6.86 & 0.568 \\
\cline { 2 - 5 } & Left & 10.06 & 5.67 & 0.296 \\
\hline \multirow{2}{*}{$6340(\mathrm{~L})$} & Right & 10.91 & 7.21 & 0.959 \\
\cline { 2 - 5 } & Left & 7.99 & 5.75 & \\
\hline \multirow{2}{*}{$4814(\mathrm{R})$} & Right & 19.03 & 7.02 & 0.435 \\
\cline { 2 - 5 } & Left & 19.33 & 6.35 & \\
\hline \multirow{2}{*}{$4814(\mathrm{~L})$} & Right & 17.55 & 7.80 & \\
\cline { 2 - 5 } & Left & 18.35 & 4.90 & \\
\hline \multirow{2}{*}{$3152(\mathrm{R})$} & Right & 14.75 & 4.19 & \\
\cline { 2 - 5 } & Left & 13.38 & 3 & \\
\hline \multirow{2}{*}{$3152(\mathrm{~L})$} & Right & 13.27 & 5.96 & \\
\cline { 2 - 5 } & Left & 14.93 & 4.56 & \\
\hline
\end{tabular}


Table 3 (Continued)

\begin{tabular}{|c|c|c|c|c|}
\hline Frequency $(\mathrm{Hz})$ post exposure 1 & Preference & $\begin{array}{l}\text { Mean } \\
\text { SPL }\end{array}$ & $\begin{array}{l}\text { Standard } \\
\text { deviation }\end{array}$ & $\begin{array}{l}\text { Mann-Whitney } \\
U \text { test }\end{array}$ \\
\hline \multirow[t]{2}{*}{$2098(R)$} & Right & 12.47 & 4.89 & \multirow[t]{2}{*}{0.756} \\
\hline & Left & 11.51 & 5.94 & \\
\hline \multirow[t]{2}{*}{$2098(\mathrm{~L})$} & Right & 11.05 & 5.13 & \multirow[t]{2}{*}{$0.055^{a}$} \\
\hline & Left & 14.7 & 7.96 & \\
\hline \multirow[t]{2}{*}{$1371(R)$} & Right & 9.71 & 6.15 & \multirow[t]{2}{*}{0.604} \\
\hline & Left & 9.24 & 4.16 & \\
\hline \multirow[t]{2}{*}{$1371(\mathrm{~L})$} & Right & 8.07 & 5.13 & \multirow[t]{2}{*}{$0.008^{\mathrm{a}}$} \\
\hline & Left & 14.16 & 3.84 & \\
\hline \multirow[t]{2}{*}{$1031(R)$} & Right & 8.1 & 4.61 & \multirow[t]{2}{*}{0.604} \\
\hline & Left & 9.78 & 1.28 & \\
\hline \multirow[t]{2}{*}{$1031(\mathrm{~L})$} & Right & 6.09 & 5.02 & \multirow[t]{2}{*}{$0.02^{\mathrm{a}}$} \\
\hline & Left & 11.21 & 1.97 & \\
\hline
\end{tabular}

${ }^{a} p$-value is significant.

Table 4 Comparison of DPOAE values at 24 hours after exposure with preference ear consideration

\begin{tabular}{|c|c|c|c|c|}
\hline $\begin{array}{l}\text { Frequency (ear } \\
\text { used) post exposure } 2\end{array}$ & Preference & $\begin{array}{l}\text { Mean } \\
\text { SPL }\end{array}$ & $\begin{array}{l}\text { Standard } \\
\text { deviation }\end{array}$ & $\begin{array}{l}\text { Mann-Whitney } \\
U \text { test }\end{array}$ \\
\hline \multirow[t]{2}{*}{$6340(R)$} & Right & 10.64 & 9.47 & \multirow[t]{2}{*}{0.796} \\
\hline & Left & 9.65 & 7.04 & \\
\hline \multirow[t]{2}{*}{$6340(\mathrm{~L})$} & Right & 11.42 & 9.50 & \multirow[t]{2}{*}{0.126} \\
\hline & Left & 6.41 & 4.90 & \\
\hline \multirow[t]{2}{*}{$4814(\mathrm{R})$} & Right & 22.41 & 8.24 & \multirow[t]{2}{*}{0.917} \\
\hline & Left & 23.20 & 4.86 & \\
\hline \multirow[t]{2}{*}{$4814(\mathrm{~L})$} & Right & 21.12 & 7.48 & \multirow[t]{2}{*}{0.756} \\
\hline & Left & 19.47 & 6.84 & \\
\hline \multirow[t]{2}{*}{$3152(R)$} & Right & 15.76 & 5.47 & \multirow[t]{2}{*}{0.717} \\
\hline & Left & 15.94 & 5.33 & \\
\hline \multirow[t]{2}{*}{3152 (L) } & Right & 14.57 & 5.33 & \multirow[t]{2}{*}{0.756} \\
\hline & Left & 15.22 & 4.53 & \\
\hline \multirow[t]{2}{*}{$2098(R)$} & Right & 12.90 & 3.3 & \multirow[t]{2}{*}{0.272} \\
\hline & Left & 14.3 & 3.82 & \\
\hline \multirow[t]{2}{*}{$2098(L)$} & Right & 12.66 & 5.04 & \multirow[t]{2}{*}{0.678} \\
\hline & Left & 12.73 & 14.49 & \\
\hline \multirow[t]{2}{*}{$1371(\mathrm{R})$} & Right & 11.75 & 5.19 & \multirow[t]{2}{*}{0.533} \\
\hline & Left & 13.31 & 3.71 & \\
\hline \multirow[t]{2}{*}{$1371(\mathrm{~L})$} & Right & 58.24 & 221.33 & \multirow[t]{2}{*}{0.113} \\
\hline & Left & 16.15 & 7.47 & \\
\hline \multirow[t]{2}{*}{$1031(\mathrm{R})$} & Right & 8.59 & 3.57 & \multirow[t]{2}{*}{0.640} \\
\hline & Left & 9.51 & 4.62 & \\
\hline \multirow[t]{2}{*}{$1031(\mathrm{~L})$} & Right & 8.17 & 4.7 & \multirow[t]{2}{*}{0.228} \\
\hline & Left & 11.24 & 2.79 & \\
\hline
\end{tabular}


Table 5 Comparison of baseline value with post exposure 1 and post-exposure 2

\begin{tabular}{|l|l|l|l|l|}
\hline \multirow{2}{*}{ Frequency (Hz) } & \multicolumn{3}{|l|}{$\begin{array}{l}\text { Comparison between baseline to } \\
\text { post exposure 1 }\end{array}$} & \multicolumn{2}{l|}{$\begin{array}{l}\text { Comparison between baseline to } \\
\text { post exposure 2 }\end{array}$} \\
\cline { 2 - 5 } & $t$-Value & $p$-Value & $t$-Value & $p$-Value \\
\hline 6340 & -1.647279 & 0.11109 & -0.952115 & 0.34949 \\
\hline 4814 & -0.799976 & 0.43071 & 1.099374 & 0.28131 \\
\hline 3152 & -1.805984 & 0.08208 & -0.594912 & 0.55686 \\
\hline 2098 & -0.230265 & 0.81962 & -0.331958 & 0.74248 \\
\hline 1371 & -1.018788 & 0.31735 & 0.842562 & 0.40688 \\
\hline 1031 & 0.638586 & 0.52847 & 1.064903 & 0.29635 \\
\hline
\end{tabular}

${ }^{*} p$-value is insignificant.

receiving phone calls. However, studies have shown that most right-handed people have a dominant left hemisphere of the brain and also left auditory hemispheric dominance. Hence, they hold the cell phone in their right hand and use the right ear for hearing. Similarly, most left-handed people hold their cell phones in their left hand. ${ }^{20}$ Even in our study, the majority of the subjects had a dominant right ear.

We observed that on immediate exposure, there was a decrease in the DPOAE level for some of the lower frequencies in the dominant ear, which reverted to the normal or near-normal within $24 \mathrm{~h}$. This implies that on prolonged exposure, the dominant ear gets more affected as compared with the non-dominant ear. A similar observation was made by Velayutham et al ${ }^{16}$ and Sharma et al, ${ }^{21}$ where the dominant ear had a significant difference in hearing compared with the non-dominant ear. It has been proved by Velayutham et al that chronic mobile phone usage can cause highfrequency hearing loss in the dominant ear. In contrast to this, we had observed that lower frequencies are more affected. This result was seen explicitly in participants with left ear dominance. Such a result could be because of fewer participants (seven) and may not be reliable. This should be replicated in a large number of participants. High-frequency hearing loss is most often missed because most routinely used audiometers assess only up to $8 \mathrm{kHz}$. When dominance of the ears is not considered, the changes in DPOAE are not significant. ${ }^{22}$ We observed similar results. This is probably due to the high absorption of electromagnetic radiation on the side the phone is held, and it decreases to almost one-tenth on the opposite side..$^{23}$

Further experiments have to be conducted to find a relation between the exposure of phones and cochlear functioning, brainstem auditory function, and the auditory cortex. Various other modalities should be explored and research should be conducted on a larger population for more conclusive results. More studies should be conducted to evaluate whether prolonged usage of mobile phones affects the onset of age-related hearing loss over many years.

\section{Conclusion}

The use of mobile phones is increasing rapidly, and hence we need to analyze whether prolonged use of mobile phones affects our health. The present study showed no significant correlation between hair cell functioning and prolonged mobile phone exposure when the ear preference was not considered. However, on consideration of one ear's dominance, there was a significant change in DPOAE of the lower frequencies on the dominant ear than on the nondominant ear.

\section{Note}

Both institutional ethical clearance and consent from participants were taken.

Conflict of Interest

None declared.

\section{References}

1 Sharma P. Evolution of mobile wireless communication networks$1 \mathrm{G}$ to $5 \mathrm{G}$ as well as future prospective of next generation communication network. Int J Comp Sci Mobile Comp 2013;2 (08):47-53

2 Dahlman E, Parkvall S, Skold J. 4G: LTE/LTE-Advanced for Mobile Broadband. 2nd ed. Cambridge, Academic Press; 2011:1-13

3 Van Leeuwen GM, Lagendijk JJ, Van Leersum BJ, Zwamborn AP, Hornsleth SN, Kotte AN. Calculation of change in brain temperatures due to exposure to a mobile phone. Phys Med Biol 1999;44 (10):2367-2379

4 Dimbylow PJ, Mann SM. SAR calculations in an anatomically realistic model of the head for mobile communication transceivers at $900 \mathrm{MHz}$ and $1.8 \mathrm{GHz}$. Phys Med Biol 1994;39(10): 1537-1553

5 Hazra A, Gogtay N. Biostatistics series module 3: comparing groups: numerical variables. Indian J Dermatol 2016;61(03): 251-260

6 Hardell L, Carlberg M, Hansson Mild K. Pooled analysis of casecontrol studies on malignant brain tumours and the use of mobile and cordless phones including living and deceased subjects. Int J Oncol 2011;38(05):1465-1474

7 Li DK, Odouli R, Wi S, et al. A population-based prospective cohort study of personal exposure to magnetic fields during pregnancy and the risk of miscarriage. Epidemiology 2002;13(01):9-20

8 Braune S, Wrocklage C, Raczek J, Gailus T, Lücking CH. Resting blood pressure increase during exposure to a radio-frequency electromagnetic field. Lancet 1998;351(9119):1857-1858

9 Oftedal G, Wilén J, Sandström M, Mild KH. Symptoms experienced in connection with mobile phone use. Occup Med (Lond) 2000;50 (04):237-245

10 Eşmekaya MA, Seyhan N, Ömeroğlu S. Pulse modulated $900 \mathrm{MHz}$ radiation induces hypothyroidism and apoptosis in thyroid cells: 
a light, electron microscopy and immunohistochemical study. Int J Radiat Biol 2010;86(12):1106-1116

11 Peyman A, Rezazadeh AA, Gabriel C. Changes in the dielectric properties of rat tissue as a function of age at microwave frequencies. Phys Med Biol 2001;46(06):1617-1629

12 Thomée S, Härenstam A, Hagberg M. Mobile phone use and stress, sleep disturbances, and symptoms of depression among young adults-a prospective cohort study. BMC Public Health 2011;11 (01):66

13 García Callejo FJ, García Callejo F, Peña Santamaría J, Alonso Castañeira I, Sebastián Gil E, Marco Algarra J. Hearing level and intensive use of mobile phones [article in Spanish]. Acta Otorrinolaringol Esp 2005;56(05):187-191

14 Hardell L, Carlberg M, Hansson Mild K. Pooled analysis of two case-control studies on use of cellular and cordless telephones and the risk for malignant brain tumours diagnosed in 19972003. Int Arch Occup Environ Health 2006;79(08):630-639

15 Hardell L, Carlberg M, Hansson Mild K. Use of mobile phones and cordless phones is associated with increased risk for glioma and acoustic neuroma. Pathophysiology 2013;20(02):85-110

16 Velayutham P, Govindasamy GK, Raman R, Prepageran N, Ng KH. High-frequency hearing loss among mobile phone users. Indian J Otolaryngol Head Neck Surg 2014;66(01, Suppl 1):169-172
17 Parazzini M, Bell S, Thuroczy G, et al. Influence on the mechanisms of generation of distortion product otoacoustic emissions of mobile phone exposure. Hear Res 2005;208(1-2):68-78

18 Paglialonga A, Tognola G, Parazzini M, et al. Effects of mobile phone exposure on time frequency fine structure of transiently evoked otoacoustic emissions. J Acoust Soc Am 2007;122(04):2174-2182

19 Parazzini M, Lutman ME, Moulin A, et al. Absence of short-term effects of UMTS exposure on the human auditory system. Radiat Res 2010;173(01):91-97

20 Seidman MD, Siegel B, Shah P, Bowyer SM. Hemispheric dominance and cell phone use. JAMA Otolaryngol Head Neck Surg 2013;139(05):466-470

21 Sharma N, Uma G, Deepak V, Sandeep R. Audiological disturbances in chronic mobile phone users. Eur J Pharm Med Res 2016;3 (10):239-242

22 Ozturan O, Erdem T, Miman MC, Kalcioglu MT, Oncel S. Effects of the electromagnetic field of mobile telephones on hearing. Acta Otolaryngol 2002;122(03):289-293

23 Ahlbom A, Green A, Kheifets L, Savitz D, Swerdlow A. International Commission for Non-Ionizing Radiation Protection Standing Committee on Epidemiology. Epidemiology of health effects of radio frequency exposure. Environ Health Perspect 2004;112 (17):1741-1754 